\title{
TEACHERS' WAY APPLYING INTEGRATED LEARNING USING INTEGRATED MODEL WITH CREATIVITY IN DEVELOPMENT Simple Aircraft as CENTRAL THEME
}

\author{
Tahmid Sabri \\ Universitas Tanjungpura, Pontianak, Indonesia \\ E-mail: tahmidsabripgsd@gmail.com
}

\begin{abstract}
This research is carried out in cycles (stages), with some step steps that are (1) The teacher makes the design of integrated learning; (2) Conducted observations by the researcher; (3) Reflection is done to see together the constraints experienced by teachers when designing; (4) Implementing subsequent actions as remedial measures for teacher inaccuracies in previous activities; (5) The next step of implementing the design that has been made; (6) Reflections on the inaccuracy in the implementation of learning (7) Take the next class action as a remedy for inaccuracy in the implementation. Then the findings of this study include (1) Distribution of time in learning, both in the design of learning and in the implementation of learning difficult for teachers to distribute it appropriately; (2) The correlation between concepts in the related field of study, is still awkward or not yet done by the teacher appropriately; (3) Drawing conclusions in learning. Teachers have difficulty directing the students to conclude from the concepts already discussed (4) The views of integrated learning teachers need to be applied in elementary schools, as they can capture some concepts from several fields of study at the same time (5) Students' view that learning in an integrated way not difficult even fun, only a small part that says difficult because not yet accustomed.
\end{abstract}

Keywords: Integrated Learning; Integrated Model

\section{INTRODUCTION}

Starting from the experience of teachers implementing integrated learning in the classroom. Teachers often experience difficulties, both in making the design of the lesson and in applying the design, meaning the design made by the teacher, or the way the teacher implements the design is not correct, and simultaneously ask teachers and students' views on whether or not the application of integrated learning in primary schools is essential. To address these problems, classroom action research is needed, in which teachers are involved collaboratively, teachers try their own, in the hope that teachers can find out directly, the various obstacles experienced by teachers so far in applying integrated learning in their own class, at least teachers can reduce the frequency inappropriateness in applying integrated learning in primary schools.

\section{MEthodology}

The research method used in this research is classroom action research method with emphasis on the way teachers apply integrated learning integrated model in class $\mathrm{v}$ elementary school. The selection of this method is based on the view that this classroom action research is able to offer new ways and procedures for improving and improving professional teachers in the classroom learning process by looking at the various indicators of process success and learning outcomes that occur in students.

\section{RESULTS AND DISCUSSION}

A. Result

Integrated learning plan integrated model with the theme of creativity of simple aircraft development can be designed by the teacher appropriately, including TPK and Impact accompanist, central 
theme, series of learning activities, learning implementation steps, and culmination activity stages, including reporting and discussion and evaluation of processes and evaluation of results. This accuracy, marked with the results of data analysis shown with $99.7 \%$.

Integrated learning plan integrated model with the theme of creativity of simple aircraft development that has been designed by the teacher appropriately, can be applied by the teacher according to the design plan that has been made, including: TPK and Impact accompanist, central theme, series of learning activities, the steps of cultivation activities, which include reporting and discussion and evaluation of process and evaluation of results, followed by followup activities. This accuracy, marked with the result of data analysis shown with percentage $98,16 \%$.

According to the view of the teacher based on the experience he has experienced through classroom action research that integrated learning is necessary once applied in primary school, given the various considerations, namely:

a. Student activities in learning, such as: asking, answering, expressing opinions, responding, reading, discussing, working, listening, and paying attention will arise during the learning takes place in a unity or interconnection resulting in a fun and conducive learning environment for students.

b. Time use occurs effectively.

c. Saving time (at the same time can capture some concepts from several fields of study).

d. Instilling democratic attitude, mutual respect, mutual openness, and others.

e. The learning is student-centered.

f. The atmosphere is lively and fun.

g. There is always a process evaluation and evaluation of results, which includes the cognitive, affective and psychomotor aspects.

According to the views of the students on the basis of experience gained during the integrated learning that "learning in this new way" needs to be done in elementary schools with the following considerations:

a. Learning in a new way is different from learning the usual way so it's fun for students $(100 \%)$.

b. Learning science, math, Bahasa Indonesia, and PPKn in this integrated way according to students no difficulty alias can be followed easily $(80,56 \%)$.

c. By learning this new way, students feel free to think, freely express opinions, free to do, free to ask, which is important in accordance with the learning objectives to be achieved under the guidance of teachers $(86.11 \%)$.

d. Learning in this new way makes the students not feel pressured about any task given by the teacher $(88.89 \%)$. e. Students do not find difficulty in group work time by learning this integrated way even happy $(72 \%)$.

f. More than $60 \%$ of the students participated in the lesson said that they did not experience difficulties when expressing their opinions or suggesting ideas, only felt slightly stiff, less accustomed (66.67\%), as well as $83.33 \%$ ).

Judging from the learning result obtained by the students showed that the average value of the individual and the average grade value ranged between $75 \%$ - $90 \%$, according to the concept of learning complete "if students master the subject matter given, at least $75 \%$, then the learning outcomes are classified good "(A.Suharsimi, 1988: 255). This provides an illustration that the way teachers apply integrated learning on a basic, from the design of making it to the application is considered appropriate.

\section{B. Discussion}

\section{Lesson Plan}

This lesson plan consists of the establishment of TPK and the impact of accompaniment, the determination of the central theme, the determination of the series of learning activities, the determination of the steps of implementation of learning, and the determination of the culmination activity stage.

a. The determination of TPK and impact of companion

In the determination of TPK and the making of companion impact initially initially teachers experience difficulty, but through this action research difficulties can be solved by teachers directly, namely TPK and the impact of accompanist who characterized the integration of the concepts with each other interconnected from several fields of study direction of the central theme of learning $(100 \%)$.

b. The determination of the central theme The central theme set by the teacher of "Simple Aircraft Development Creativity", based on research results on the action that the theme is correct is marked by the following:

1) Simple

2) Interesting

3) Can capture the related concepts from several fields of study

4) According to the level and ability of the learners $(100 \%)$.

c. Determination of a series of learning activities From the steps of the series of activities planned by teachers in the learning, the plan is quite appropriate, except the time distribution on the plan of the stages of learning implementation, there are still obstacles for teachers, because it is still predictive, not in the actual stage of implementation. Distribution of time in the design is an illustration of the use of time when the implementation of integrated learning is 
appropriate, therefore appropriate time estimates, from the initial action plan, core activities to the learning end activities so that time can be used effectively according to the lesson plan. In general, however, the planned action steps designed by the teachers have met expectations $(98.3 \%)$.

d. Determine the steps of implementation of learning The sequence of integrated learning activities involves initial activities, core activities and end activities that are the culmination of integrated learning. These activities are interconnected with each other, and more emphasizing activity in children. The core activities begin with the development of concepts related to raising various activities and creativity of children in learning by using various methods and strategies. This design has been poured teachers in lesson plans $(100 \%)$.

e. Determination of culmination activity stage This stage is part of this activity, which is the culmination of all integrated learning activities. This stage includes reporting by students and speakers and is followed by evaluation and other activities. All these plans have been properly articulated by the teacher in the lesson plan (100\%).

2. Implementation of Learning

a. Determination of TPK and impact of companion TPK that has been determined by the teacher in the design of learning is a real picture to be addressed or to be achieved so that the various activities undertaken focused on the TPK. The teacher's efforts to achieve that goal have been accomplished correctly. While the expected impact of accompanist during the implementation of learning cannot be clearly described, because it is predicted in the future. Here the teacher gives an appeal to disseminate the information of TPK at the beginning of the learning simultaneously.

b. The determination of the central theme

The central theme is "The creativity of simple aircraft development". In the implementation of learning, all the concepts discussed by teachers including various attitudes and skills are always interconnected and overlapping towards an agreed central theme that encourages children to perform activities and activities related to the development of simple aircraft. This effort has been done by teachers properly, although there are still obstacles experienced by teachers, the controls can eventually be resolved by the teacher well $(95 \%)$.

c. The design of learning activities

The design of learning activities that have been poured teachers in the lesson plan can already be implemented by teachers with good enough and running smoothly. In this case, it is only a matter of time distribution that is not always appropriate with the time distribution already planned by the teacher. Because this integrated learning is applied through action research with stages, the inaccuracy can be overcome after reflection between the teacher and the researcher and other parties. Thus the design of various activities that can be done properly $(98.3 \%)$.

d. Steps of implementation of learning

Initial activities, core activities, and end activities can already be implemented by teachers appropriately, starting with the conclusions of the teacher-directed children are still in difficulty, but ultimately can be improved by the teacher at the next learning meeting stage $(97.5 \%)$.

e. Determination of culmination activity stage Stages of this activity include reporting by the child as a result of his / her learning creativity and followed up by the teacher with the discussion, through questioning, class discussion, and explanation by the teacher, followed by evaluation activities both evaluation process and evaluation result. All of these activities have been done by the teacher with $100 \%$ accuracy.

3. The state of the student while following the lesson Implementation of integrated learning basically serves as a driver of student learning power to construct knowledge that is being studied. Therefore, integrated learning can be regarded as an approach or a strategy of learning.

Various methods and other methods developed by the teacher so as to make students preoccupation with learning. Students are enthusiastic and actively follow the learning process conducted by teachers in an integrated manner. Students ask each other questions and discuss problems solved by the teacher so that they are creative and happy to do the task given tana feel burdened at least from the beginning until the end of learning. Here students are given the freedom to express opinions, ask questions and comment on any opinions by others.

The atmosphere is lively and fun, students are tireless and do not feel pressured over every task given by the teacher. If the teacher is not responsive and creative can lead to uncontrolled classes and always lack time. But the teacher is always reflective, any problems that arise will always be resolved properly so that the atmosphere of learning in the classroom is still going well. The state of the student at all times is controlled by the teacher and any assigned tasks by the group, will be reported and discussed together to obtain the perfection of the work of the discussion.

This fact is seen in the course of integrated learning. Indeed at first, the students are somewhat passive, less daring to ask let alone express opinions, but in the end, the students happened as what has been mentioned above with the level of $97.14 \%$ significance. 


\section{The value of student learning outcomes}

Judging from the learning outcomes obtained by the students (in the previous table) shows that the application of integrated learning to elementary students can provide meaningful meaning for student learning, proved the average value of the individual and the average grade ranges from $75 \%-90 \%$. According to the concept of complete learning, if each student can master the subject matter given by the teacher, at least $75 \%$ of all material taught then the student learning outcomes are quite good (A. Suharsimi, 1988: 255). Thus it can be drawn a conclusion that the integrated learning that has been implemented in elementary school has been implemented properly.

5. Results of Interviews with Teachers and Students:

a. Teacher:

The results of interviews with teachers applying integrated learning include: "student activity, the use of time, the necessity of integrated learning in SD sustainably, the advantages and disadvantages of integrated learning, delivery strategies, impressions and messages after applying integrated learning, suggestions and criticisms provided as well as evaluation of learning ". follows:

The details of the interview are as

1) Student activity in learning

These activities include: asking, reading, discussing, working, listening, watching, answering, and responding. Various types of these activities during the learning takes place, proceeding in one unit or interrelationships so that there are a fun and conducive learning atmosphere.

2) Time use occurs effectively

3) Considering the advantages, such as: saving time, being able to clarify several concepts at the same time, democratizing democracy; etc., therefore, integrated learning needs to be developed in SD in a sustainable manner, even if there are constraints on certain matters such as timeliness, grouping of students and not supported by adequate means.

4) d. The learning is student-centered.

5) The atmosphere is lively and fun.

6) There is always evaluation of processes and outcomes, both cognitive, affective, psychomotor and other aspects.

From the above interviews, it is clear that integrated learning in elementary schools needs to be applied to elementary students, considering the various positive aspects, such as: active, creative, living class, fun, time-effectiveness, can interact concepts at the same time, embedded democratic attitudes, student-centered learning and so on. b. Student:

From some opinions or views of students on integrated learning in primary schools can be grouped as follows:

1) Integrated learning in primary school needs to be implemented $(97.22 \%)$.

2) Learning in a new way (integrated learning) is different from learning the usual way (100\%).

3) Learning Science, Mathematics, Bahasa Indonesia, IPS, and PPKn by combining each other according to students no difficulty $(80.56 \%)$.

4) Of the five subjects: Science, Mathematics, Indonesian, IPS, and PPKn according to most students there is no difficult to learn by means of integrated learning integrated model $(61.11 \%)$.

5) Learning in this new way, students feel free to think, free to express opinions, free to do, free to ask, which is important in accordance with the learning objectives to be achieved under the guidance of teachers $(86.11 \%)$.

6) Learning in this new way students do not feel pressured on any task given teachers $(88.89 \%)$

7) Learning in this new way (Learning integrated), most students say happy $(88.89 \%)$.

8) Learning by way of connecting science subjects with other subjects generally the students say can be followed / easy to follow $(75 \%)$

9) Many students say that at group work time this new way of learning has no difficulty $(72 \%)$

10) More than $60 \%$ of all students view that there is no difficulty in expressing opinion $(66.67 \%)$.

11) Most students think that there is no difficulty in asking questions $(83.33 \%)$.

Thus it can be highlighted that the implementation of integrated learning in elementary schools, according to the students' perspective needs to remember the existence of various advantages, such as free opinion, free to ask, free to do, fun learning atmosphere, intercourse relationship and so forth.

6. Score of Students' Learning Results

From the learning result obtained by the students shows that the average value of the individual and the average grade value ranges from $75 \%-90 \%$, according to complete learning theory "if students master the subject matter given, at least $75 \%$, then the learning outcomes are already quite good "(A.Suharsimi, 1988: 255). This provides an illustration that the way teachers apply integrated learning on a basic, from design to application has been considered appropriate. 


\section{IV.CONCLUSIONS}

a. Integrated learning plan integrated model with the theme of creativity of simple aircraft development can already be designed by the teacher appropriately, including:

1. Rearing of TPK and Impact accompanist

2. Determination of the central theme

3. Determination of a series of learning activities

4. Determine the steps of implementation of learning

5. Determination of culmination activity stages, including reporting and discussion and evaluation of process and evaluation of results (99.7\%).

b. Integrated learning plan integrated model with the theme of creativity of simple aircraft development that has been designed by the teacher appropriately, can be applied by the teacher appropriately according to plan include:

1. TPK and Impact accompanist

2. Central theme

3. A series of learning activities

4. Step-by-step implementation of learning

5. Stages of culmination activities, which include reporting and discussion and evaluation of process and evaluation of results, followed by follow-up activities. (98.16\%).

c. According to the view of the teacher based on the experience he has experienced through classroom action research that integrated learning is necessary once applied in primary school, given the various considerations, namely:

1. Student activities in learning, such as: asking, answering, expressing opinions, responding, reading, discussing, working, listening, and paying attention will arise during the learning takes place in a unity or interconnection resulting in a fun and conducive learning environment for students.

2. Time use occurs effectively.

3. Saving time (at the same time can capture some concepts from several fields of study).

4. Instilling democratic attitude, mutual respect, mutual openness, and others.

5. The learning is student-centered.

6. The atmosphere is lively and fun.

7. There is always a process evaluation and evaluation of results, which includes the cognitive, affective and psychomotor aspects.

d. According to the views of the students on the basis of experience gained during the integrated learning that "learning in this new way" needs to be done in elementary schools with the following considerations:

1. Learning in a new way is different from learning the usual way so it's fun for students $(100 \%)$.
2. Learning science, math, Bahasa Indonesia, and PPKn in this integrated way according to students no difficulty alias can be followed easily $(80,56 \%)$.

3. By learning this new way, students feel free to think, freely express opinions, free to do, free to ask, which is important in accordance with the learning objectives to be achieved under the guidance of teachers $(86.11 \%)$.

4. Learning in this new way makes the students not feel pressured about any task given by the teacher $(88.89 \%)$.

5. Students do not find difficulty in group work time by learning this integrated way even happy $(72 \%)$.

6. More than $60 \%$ of the students participated in the lesson said that they did not experience difficulties when expressing their opinions or suggesting ideas, only felt slightly stiff, less accustomed $(66.67 \%)$, as well as $83.33 \%$ ).

Judging from the learning result obtained by the students shows that the average value and the average grade is between $75 \%-90 \%$, according to the concept of complete learning "if students master the subject matter, at least $75 \%$, then the learning outcomes are already quite good" (A.Suharsimi, 1988: 255). This provides an illustration that the way teachers apply integrated learning on a basic, from design to application has been considered appropriate.

\section{ACKNOWLEDGMENTS}

a. Mr/Mrs. Director General of Higher Education Department of National Education and staff.

b. Mrs. Ir. Agustine Lumangkun, M. Sc, and staff of Research Institute Universitas Tanjungpura Pontianak.

c. The Dean of Faculty of Teacher Training and Education Universitas Tanjungpura Pontianak.

d. The Head of the National Education Branch Office Kotamadia Pontianak.

e. Mrs. Dra. Maimun Syamsul Hadi as the Principal of SD 32, and Ibu Kristina, A.Ma teacher of grade V SD 32 Kotamadia Pontianak, along with other parties who have participated in collaboration in this research.

\section{REFERENCES}

Aswin, H.F. 1996. Psikologi Perkembangan Anak. Jakarta: Depdikbud.

Asy’ari, M. 1997. Pembelajaran Terpadu Antar Bidang Studi Sebagai Variasi Pengajaran di SD dengan Tema Sentral Bidang IPA. (Tesis). Bandung: PPS UPI Bandung. 
Depdikbud. 1995. Kurikulum Pendidikan Dasar/ GBPP, Kelas V Sekolah Dasar Tahun 1994. Jakarta: Dirjen DIKTI.

Ertikanto, C. 1998. Pembelajaran Terpadu Model Integrated (Makalah). Bandung: PPS UPI Bandung.

Fogarty, R. 1991. How To Integrated The Curricule. Skylight Publishing, Inc. Palatine, Illinois.

Hopkins, D. 1993. A Teacher's Guide to Classroom Research. Second Edition Buckingham, Philadelphia: Open University Press.

Joni, T.R. 1997. Pembelajaran Terpadu. Naskah untuk Pelatihan Guru Pamong SD, BP3GSD, DIKTI di Yogyakarta, Tanggal 4-16 Agustus 1997.

Kartadinata, S \& Dantes. 1997. Landasan-Landasan Pendidikan Sekolah Dasar. Jakarta: Depdikbud.

Muhadjir, N. 1996. Pedoman Pelaksanaan Penelitian Pendidikan Kelas, Bagian Keempat: Analisis dan Refleksi. Yogyakarta: Dirjen DIKTI.

Peter, T, Schubeck, K, \& Hopkins. 1995. A. Thematic Approach: Theory and Practice at the Aleknagik School. Phi Delta Kappan.76 (8).633-636.

Srini., M.I. 1997. Pendidikan Ilmu Pengetahuan Alam. Jakarta. BP3 GSD: Direktorat Jendral Pendidikan Tinggi (DIKTI).

Suyanto. 1997. Pedoman Penelitian Tindakan Kelas. Bagian Kesatu Yogyakarta: Direktorat Jendral Pendidikan Tinggi (DIKTI).

Tim Pengembang PGSD. 1997. Pembelajaran Terpadu D-II PGSD dan S 2 Pendidikan Dasar. Jakarta : Direktorat Jendral Pendidikan Tinggi (DIKTI). 